DOI https://doi.org/10.30525/978-9934-588-81-5-1.48

\title{
РОЛЬ «ВЕГЕТАТИВНОГО ПАСПОРТА» ХВОРИХ В ПАТОГЕНЕЗІ РІЗНИХ ФОРМ РЕВМАТОЇДНОГО АРТРИТУ ТА КОМОРБІДНОСТІ
}

\author{
Сокрут О. П. \\ кандидат медичних наук, \\ доцент кафедри реабілітаційної та спортивної медицини \\ Донеиький наиіональний медичний університет \\ Сокрут М. В. \\ науковий співробітник \\ Науково-дослідницький інститут травматологї та ортопедї \\ Донеиького національного медичного університету \\ м. Лиман, Донеиька область, Україна
}

Ревматоїдний артрит (РА) належить до найбільш частих запальних хвороб суглобів, його поширеність серед населення сягає 1-3\%. [1]. У механізмах формування супутньої патології та фатальних серцевосудинних ускладнень РА провідна роль, окрім іншого, відводиться вегетативній дисфункції (ВД) [2]. РА вважається хронічним системним автоімунним захворюванням сполучної тканини 3 виразними змінами вегетативної нервової системи (ВНС). Виділяють серопозитивні та серонегативні форми РА. Більшість авторів наводять дані про переважання у хворих на РА симпатотонії, але є повідомлення, що вказують на зниження тонусу як симпатичної, так і парасимпатичної ланок нервової системи [3, 4]. Найбільш інформативним методом діагностики вегетативного тонусу є спектральний аналіз ЕКГ пацієнтів. Підкреслюється роль ВНС при залученні до патологічного процесу при РА периартикулярних тканин і скелетних м'язів [5,6]. Якщо у хворих на РА ацетилхолін стимулює синовіальний остеогенез, то норадреналін його пригноблює $[7,8]$. У патогенетичних побудовах захворювання важливу роль відіграють інтраартикулярні ненейронні холінергічні зв'язки [9] та гомеокінез пацієнта [10], а прояви експериментального артриту у тварин зменшуються нейростимуляцією холінергічного шляху через уведення електроду в блукаючий нерв [11]. Було показано, що тварини із слабкою М3-мускариновою рецепцією ацетилхоліну мають більш тяжкий перебіг суглобового синдрому i великі зсуви рівнів прозапальних цитокінів і хемокінів в крові [7]. 
Встановлено важливе значення внутрішньоклітинного кальцію, як універсального месенжера та «вегетативного паспорту» в патогенезі різних форм захворювання і коморбідності, що покладено в основу «вегето-гомеокінетичної теорії патології» [10]. При домінуючій вагоінсуліновій дисфункції виявляють кальцієвий дефіцит. Адреналін, напроти, підвищує вміст кальцію в клітинах, який, гіпотетично, буде визначати форму коморбідності при РА. З'ясування ролі «вегетативного паспорту», який пов'язують 3 щільністю та сенситивністю адренорецепторів хворих на РА та рівнем внутрішньоклітинного кальцію у них, сприятиме визначенню нових ланок патогенезу форми захворювання та коморбідності, дозволить розробити прогностичні критерії перебігу хвороби і ефективність лікувальних заходів, підвищити якість терапії пацієнтів.

Обстежено 173 хворих на РА у віці від 18 до 79 років (в середньому $45,8 \pm 0,90$ років). Тривалість маніфестації захворювання склала $10,0 \pm 0,56$ років. Серопозитивний за $\mathrm{RF}(\mathrm{RF}>14$ мО/мл) варіант РА встановлено в $74,6 \%$ випадків, серопозитивний за аССР (аССР>17 О/мл) - в 72,8\%. Ці хворі віднесені до першої групи. Пацієнти з серонегативною формою РА ввійшли до другої групи. Позасуглобову (системну) форму хвороби діагностовано в 37,0 \% спостережень, системний остеопороз - в 66,5 \%. Епіфізарний остеопороз виявлено у 89,0 \% від числа хворих, субхондральний склероз - у 53,2\%, остеокістоз - у 87,9\%, остеоузури - у 47,4\%, асептичний остеонекроз - у 6,9 \%, артрокальцифікати - у 23,1\%, інтраартикулярні тіла Штайді - у 5,2 \%, хондромні тіла - у 23,7 \%, тіла Гоффа - у 3,5\%, кісти Бейкера - у 16,8 \%. Тендовагініти діагностовано в 42,2 \% спостережень РА, ентезопатії - в 19,1\%. Всім хворим виконували рентгенологічне дослідження суглобів, крижовоздухвинних і хребцевих зчленувань, а також органів грудної клітки («Multix-CompactSiemens», Німеччина), ультразвукове дослідження суглобів, внутрішніх органів, щитоподібної залози і лімфатичних вузлів («EnvisorPhilips», Нідерланди), двохенергетичну рентгенівську остеоденситометрію проксимального відділу стегнової кістки («QDR-4500-DelphiHologic», США). Оцінювали метакарпальний індекс Барнетта-Нордіна (BNI) та індекс мінеральної щільності кістки (BMD), проводили електрокардіографію («МІДАК-ЕК1Т», Україна) та ехокардіографію («Acuson-Aspen-Siemens», Німеччина). Варіаційну пульсометрію виконували за допомогою приладів «Кардіолаб-2000» (Україна). Спектральний аналіз п'ятихвилинних послідовностей RR-інтервалів ЕКГ проводили методом швидкого перетворення Фур'є. На зареєстрованих 
ритмокардіограмах визначали потужності LF і HF, підраховували співвідношення LF/HF як SVI, а також оцінювали нормовані LF (LFN) i HF (HFN). HF асоціювався з еферентною активністю блукаючого нерва, a LF - з активністю барорефлекторних, переважно, симпатичних впливів. В рамках вивчення виразності ВД визначали логарифм квадрату KVI, досліджували VSI. У сироватці крові визначали вміст тих хімічних макро- і мікроелементів, які беруть участь у метаболізмі кісткової тканини (Ca, $\mathrm{Mg}, \mathrm{P}, \mathrm{Pb}, \mathrm{Sr})$, з використанням спектрометрів «IRIS-Intepid-II-XDL» i «SolAAr-Mk2-MOZe» (Велика Британія). Форму коморбідності визначали за індексом нормованого внутрішньоклітинного кальцію. В якості контролю обстежено 40 практично здорових людей у віці від 18 до 63 років, серед яких було 11 чоловіків і 29 жінок. Статистичну обробку отриманих результатів проведено за допомогою комп'ютерного варіаційного, непараметричного, кореляційного, регресійного, одно- (ANOVA) та багатофакторного (ANOVA/MANOVA) дисперсійного аналізу (ліцензійні програми «Microsoft Excel» i «Statistica-Stat-Soft», США). Оцінювали середні значення, їх стандартні відхилення та похибки, коефіцієнти параметричної кореляції Пірсона і непараметричної Кендалла, критерії дисперсії Брауна-Форсайта, множинної регресії, Стьюдента, УӥлкоксонаРао, Макнемара-Фішера, достовірність статистичних показників.

У хворих першої досліджуваної групи серопозитивної за RF спостерігали низькі показники мінеральної щільності кістки за даними денситометрії, домінування вагусної активності згідно зі спектральним аналізом ЕКГ, підвищення в крові аССР і фібриногену, низький рівень внутрішньо-клітинного кальцію (кальцієвий індекс $<1,0$ ), що вказувало на кальцій-дефіцитну коморбідність і супроводжувалося наявністю остеопорозу, серозитів, пневмоніта, кист Бейкера та діастолічною дисфункцією лівого шлуночка серця. Зміни адсорбційнореологічних властивостей крові при серопозитивному РА супроводжувалися підвищенням статичного поверхневого натягу в 70 \% випадків, інтегральний стан міжфазної активності, релаксаційних та в'язкоеластичних характеристик крові вказували на в'ялий перебіг запального процесу. Остеопороз спостерігався у $2 / 3$ хворих цієї групи. Тяжкість перебігу РА корелювала $з$ показниками щільності кістки і параметрами варіаційної пульсометрії. У хворих другої групи з серонегативною формою PA за RF тяжкість вегетативних розладів була тісно пов'язана 3 наявністю атеросклероза та інтраартикулярних артрокальцинатів - кальцій-залежна коморбідність, дигітальним артеріїтом і дисциркуляторною ішемічною енцефалопатією. Дані варіаційної 
пульсометрії відображали домінування симпатотонії, а колоїднореологічні властивості крові вказували на її згущення.

Результати дослідження показали, що «вегетативний паспорт» визначає інтегральні клініко-лабораторні та інструментальні ознаки РА. При цьому тип ВНС формує серопозитивний варіант РА при ваготонії і прямо корелює з темпами прогресування патології суглобів і кальцій-дефіцитною формою коморбідності. У симпатотоніків частіше спостерігається серонегативна за RF форма хвороби на тлі кальційзалежної коморбідності. Результати медикаментозної патогенетичної терапії РА залежать від наявності ВД, причому, ефективність лікувальних заходів більше при симпатотонії порівняно 3 ваготонією. В комплексному лікуванні хворих на РА виявився позитивним вплив перемінного магнітного поля на суглоби та потилицю (вегетосуглобова методика) з одночасним призначенням міорелаксантів, що за ефективністю значно перевищує традиційні терапевтичні заходи.

\section{Література:}

1. Галушко Е.А., Насонов Е.Л. Распространенность ревматических заболеваний в России. Альманах клинической медицины. 2018. № 1. T. 46. С. 32-39.

2. Koopman F.A., Van Maanen M.A., Vervoordeldonk M.J. Balancing the autonomic nervous system to reduce inflammation in rheumatoid arthritis. J Intern Med. 2017. Vol. 282 No 1. P. 64-75.

3. Коршунова Г.Н. Оценка вегетативных изменений у больных ревматоидным артритом на основе применения опросника А.М. Вейна. Крым. тер. журн. 2011. № 2. С. 111-115.

4. Zanoni J.N., Bossolani G.D. Does the rheumatoid arthritis affect the enteric nervous system? Arg. Gastroenterol. 2019. Vol. 56. No 2. P. 113-117

5. Новикова Д.С., Попкова Т.В., Герасимова Е.В. Динамика частоты сердечных сокращений, показателей вариабельности ритма сердца и величины интервала Q-T у женщин с ревматоидным артритом на фоне лечения ритуксимабом. Науч.практ. ревматология. 2014. № 3. T. 52. C. $270-276$.

6. Houweling P., Kulkarni R.N., Baldock P.A. Neuronal control of bone and muscle. Bone. 2015. Vol. 80. No. 11. P. 95-100.

7. Beckmann J. Schubert H. G. Morhenn Expression of choline and acetylcholine transporters in synovial tissue and cartilage of patients with rheumatoid arthritis and osteoarthritis. Cell. Tissue. Res. 2015. Vol. 359. No 2. P. 465-477. 
8. Muschter D. Sympathetic neurotransmitters modulate osteoclastogenesis and osteoclast activity in the context of collageninduced arthritis. PLoS One. 2015. Vol. 10. No 10. e.0139726. https://doi.org/10.

9. Jänig W., Green P.G. Acute inflammation in the joint: its control by the sympathetic nervous system and by neuroendocrine systems. Auton. Neurosci. 2014. Vol. 182. No 5. P. 42-54.

10. Фізична, реабілітаційна та спортивна медицина: підручник / В. М. Сокрут та ін; за заг. ред. В. М. Сокрута. Краматорськ: Каштан. 2019. $480 \mathrm{c}$.

11. Levine Y.A., Koopman F.A., Faltys M. Neurostimulation of the cholinergic anti-inflammatory pathway ameliorates disease in rat collageninduced arthritis. PLoS One. 2014. Vol. 9, No 8. E. 104530.

DOI https://doi.org/10.30525/978-9934-588-81-5-1.49

\title{
ВИПАДОК ДІАГНОСТИКИ ТА ЕНДОСКОПІЧНОГО ВИДАЛЕННЯ ПІСЛЯОПЕРАЦИЙНОГО СТОРОННЬОГО ТІЛА НАДПЕЧІНКОВОГО ПРОСТОРУ
}

\author{
Ступницький А. І. \\ лікар-ендоскопіст, хірург \\ Медичний иентр Святої Параскеви \\ Гула Г. В. \\ кандидат медичних наук, \\ лікар-ендоскопіст \\ Медичний ичентр Святої Параскеви \\ Ступницька Н. Д. \\ лікар-радіолог \\ Медичний иентр Святої Параскеви \\ Шев'як П. І. \\ лікар-хірург \\ Медичний центр Святої Параскеви \\ м. Львів, Украӥна
}

Вступ. Проблема післяопераційних сторонніх тіл (ПСТ) була й залишається актуальною упродовж усієї історії хірургії $[2,6,10,11]$. ПСТ є ятрогенним хірургічним післяопераційним ускладненням, частота якого - від 0,3 до 1 на 1000 черевних операцій $[2,7,11]$. Смерт- 